\title{
COMPARISON OF DIFFERENT CONVERTERS FOR PV SOLAR SYSTEM
}

\author{
J. Krishnamoorthy \\ Department of EEE \\ A.K.T Memorial college of Engineering and Technology \\ Kallakurichi, Tamilnadu, India
}

\begin{abstract}
The paper proposes the advance DCDC converter by LUO Converter. In conventional method Boost Converter (BC) complexity of DC link voltage level control. Speed control means intentional change of the drive speed to a value required for performing the specific work process. The dc motors are used in various applications such as industries, Robotics etc. DC drives are less complex for DC to DC conversion as compare to AC to DC conversion. A LUO converter is DC to DC converter used for speed control of DC motor due to its advantages over fundamental DC to DC converter.
\end{abstract}

Keywords-DC-DC Converter, LUO Converter, Speed control, DC Motor, cuk converter, sepic converter

\section{INTRODUCTION}

DC-DC converters convert electrical power provided from a source at a certain voltage to electrical power at a different dc voltage. Electrical energy, though available extensively from storage sources such as batteries, or from primary converters such as solar cells, distributed ac mains, is hardly ever used as such at the utilization end. The DC-DC conversion technique was introduced in the year of 1920s. During that period, simplest DC-DC converter was developed for low voltage applications like (potential-meter, rheostat, and etc.) the converter dos not performed well, because it has poor efficiency, high losses, and low voltage transfer gain . Therefore, they intend to develop the DC-DC converter with high efficiency as well as conversion of one voltage level to another voltage level. At the same time period the AC-AC conversion converts the one voltage level to another voltage level using transformer. Before the Second World War basic types of DC-DC converters was fed for industrial applications. After the world war, the communication system was enhanced to the maximum converter topology was developed (above 500 DC-DC converters topologies offered in the world and it is continuous improvement since 1920s) [1]. In the year

\author{
V. Suganya \\ Department of EEE
}

A.K.T Memorial college of Engineering Technology

Kallakurichi, Tamilnadu, India

of 2001, the DC-DC converters have been classified into six generations, which was reported by Fang Lin LUO .In all DC-DC converters, the output voltage and power transfer efficiency are limited by parasitic element although in theory the traditional converter can produce high voltage and with high efficiency [2]. LUO converter is new developed DC-DC converter. In recent years, all modern electronic systems require power supply with high reliability, high cheap topology in simple structure, low weight with high quality and capability of easy control [3].DC-DC Buck-Boost converter is used for step-up and stepdown the voltage. Voltage transfer gain for BuckBoost converter is low as compare. A DC-to-DC converter in which converts a source of direct current (DC) from one voltage level to another. Most DC to DC converters also adjust the output voltage. Some exceptions include high- efficacy drive sources, which are a type of DC to DC converter that control the current during the drive, and easy accuse pumps which twice or triple the crop voltage. Electronic switchmode DC to DC converters change one DC voltage stage to one additional, by storing the input energy in the short term and then releasing that energy to the output of a dissimilar voltage. The storage can be in also magnetic field storage elements inductors, transformers or electric field storage elements capacitors. This conversion method is more power efficacy often $75 \%$ to $98 \%$ than linear voltage imperative, which dissipates surplus power as heat. of the charging voltage that is, the relation of on/off time, the quantity of power transfer can be controlled. Regularly, this is functional to organize the output voltage, while it could be practical to DC-to-

\section{IMPORTANCE OF DC-DC CONVERSION IN DRIVES}

A DC-to-DC converter in which converts a source of direct current (DC) from one voltage level to another. Most DC to DC converters also adjust the output voltage. Some exceptions include high- efficacy drive sources, which are a type of DC to DC converter that control the current during the drive, and easy accuse pumps which twice or triple the crop voltage. 
Electronic switch-mode DC to DC converters change one DC voltage stage to one additional, by storing the input energy in the short term and then releasing that energy to the output of a dissimilar voltage. The storage can be in also magnetic field storage elements inductors, transformers or electric field storage elements capacitors. This conversion method is more power efficacy often $75 \%$ to $98 \%$ than linear voltage imperative, which dissipates surplus power as heat. DC-to-DC converters, energy are occasionally stored into and free from a magnetic field in an inductor or a transformer, classically in the range from $300 \mathrm{kHz}$ to $10 \mathrm{MHz}$. By regulating the duty cycle of the charging voltage that is, the relation of on/off time, the quantity of power transfer can be controlled. Regularly, this is functional to organize the output voltage, while it could be practical to organize the input current, the output current, or maintain a constant power. Transformer-based converters may give isolation between the input and the output. In common, the term "DC-to-DC converter" refers to switching converters.

\section{BOOST CONVERTERS IN DRIVES}

The Boost Converter is a step-up DC/DC voltage. It works in second quadrant operation. The output voltage increases in arithmetic progression. Boost converter which has the limitation over DC link voltage level and complexity of control circuit.

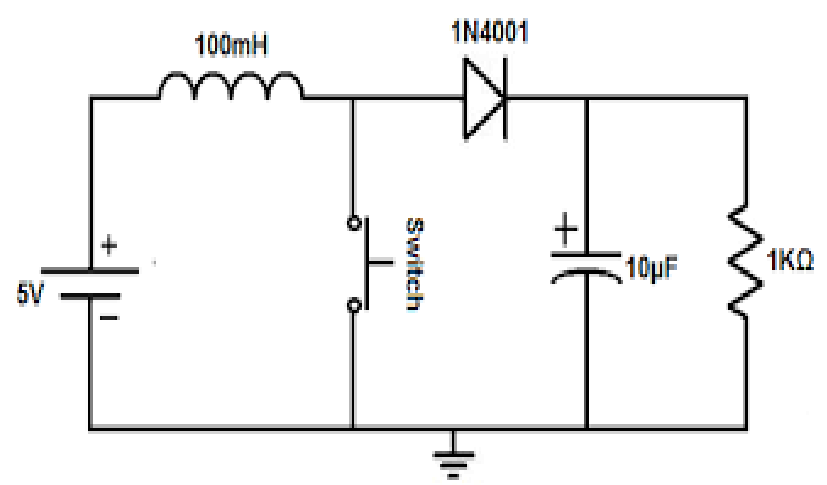

Figure 2.Boost Converter.

V out $=1 / 1-\mathrm{D}$

I in $=1 / 1-D$ Io

From Equation, the output voltage can be adjusted by changing the magnitude of the signal duty cycle switching. This conditions can be maintained during the load under normal conditions. When the load changes, there will be a change at output voltage. If the load is too large (small resistance value), the output voltage will decrease. The actual speed and reference speed are compared and the error of the speed is given as input to PI controller. Based on the proportional gain valueand the integral gain value, the PI controller regulates an output. These output given to the PWM generator. PWM generator generate get pulses, these pulse are applied to switch and eliminating the constant speed of the DC Motor.

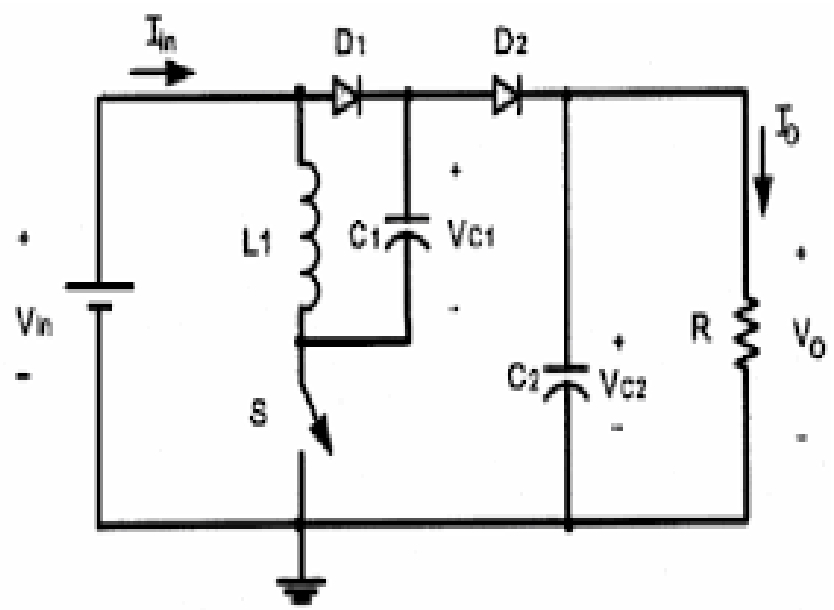

Figure 3.The basic circuit of LUO Converter.

\begin{tabular}{|c|c|c|}
\hline Parameter & $\begin{array}{l}\text { Boost } \\
\text { converter }\end{array}$ & $\begin{array}{l}\text { LUO } \\
\text { converter }\end{array}$ \\
\hline $\begin{array}{r}\text { Input } \\
\text { Voltage }\end{array}$ & $80 \mathrm{~V}$ & $80 \mathrm{~V}$ \\
\hline $\begin{array}{l}\text { Switch ,,Se } \\
\text { used in DC- } \\
\text { DC } \\
\text { Converter }\end{array}$ & MOSFET & MOSFET \\
\hline $\begin{array}{c}\text { Duty } \\
\text { cycle }(\mathrm{k})\end{array}$ & 0.5 & 0.5 \\
\hline Inductor (L) & $2.5 \mathrm{MH}$ & $2.5 \mathrm{MH}$ \\
\hline $\begin{array}{l}\text { Capacitor ( } \\
\text { C ) }\end{array}$ & $100 \mu \mathrm{F}$ & $\begin{array}{l}400 \mu \mathrm{F} \\
800 \mu \mathrm{F}\end{array}$ \\
\hline Motor & $\begin{array}{l}5 \mathrm{HP} 240 \mathrm{~V} \\
1750 \mathrm{RPM} \\
\text { Field } \\
\text { voltage }=150 \\
\text { V }\end{array}$ & $\begin{array}{l}5 \mathrm{HP} 240 \mathrm{~V} \\
1750 \mathrm{RPM} \\
\text { Field } \\
\text { voltage }=150 \\
\text { V }\end{array}$ \\
\hline Efficiency & Low & High \\
\hline
\end{tabular}



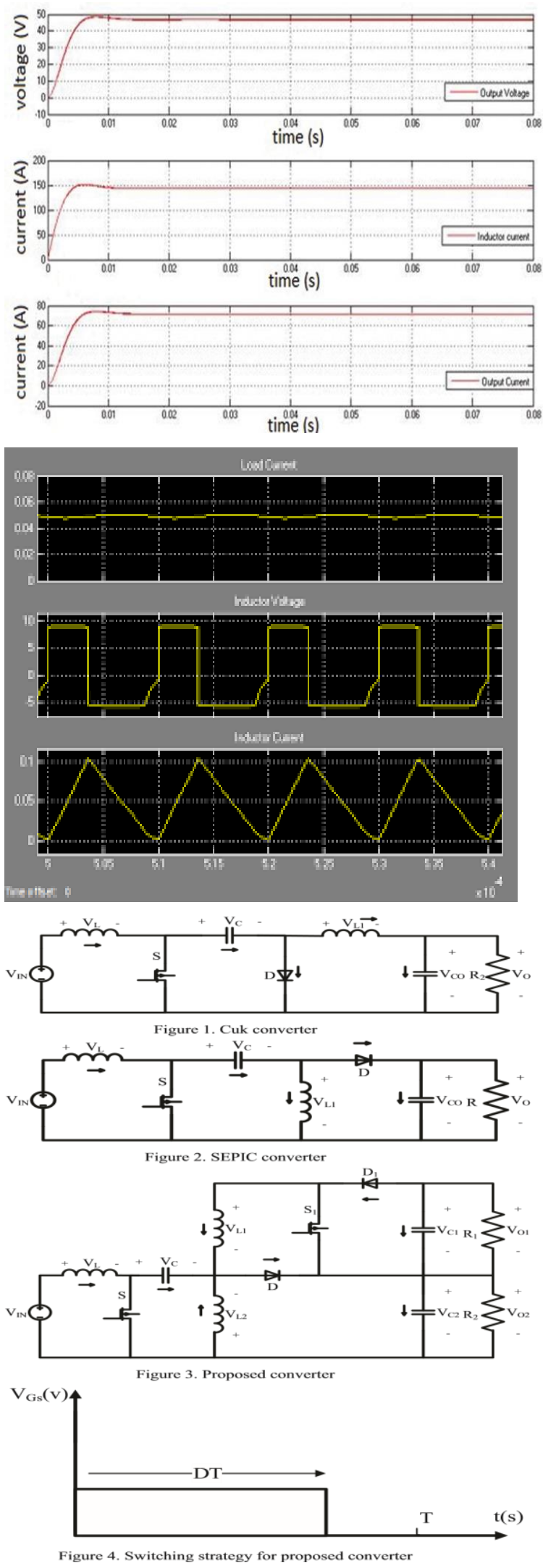

IV.

PROPOSED TOPOLOGY ANALYSIS

If the switching pattern of Fig 4 is applied to the switches, two different operation modes are obtained based on the switches condition. These two modes will explained in next sections. All the parameters used in this paper are explained in Table 1.

Table 1. CIRCUIT VARIABLES

\section{Parameters Introduction}

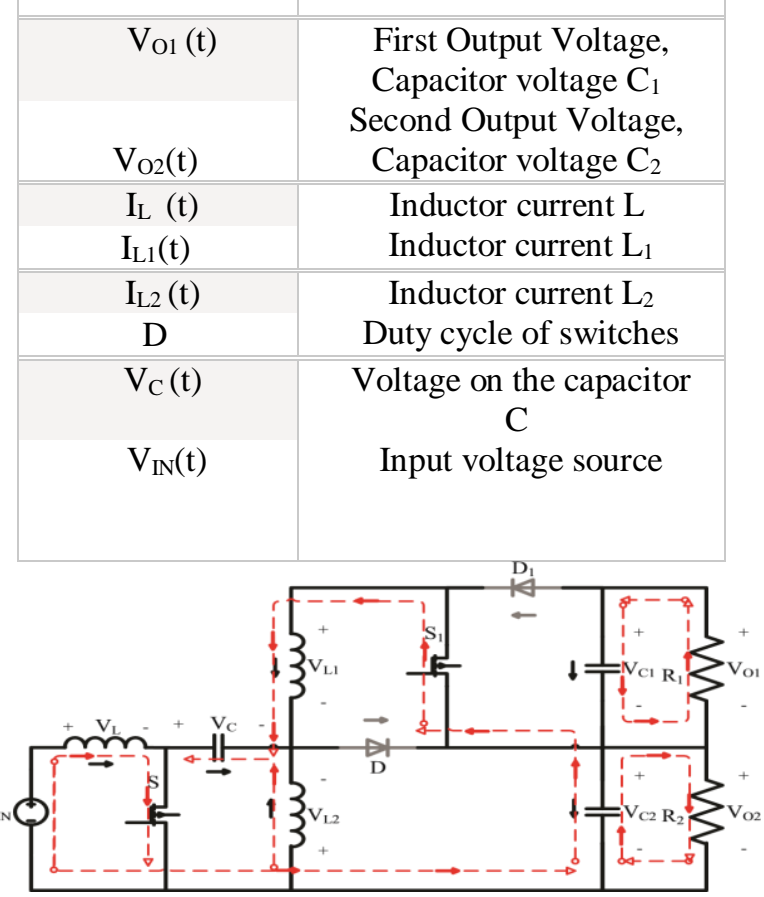

Figure 5. First sub circuit of proposed converter

\section{A. Operation mode $1 \quad 0<t<D T$}

In this switching mode both switches are $\mathrm{ON}$ and diodes are OFF. In Fig 5 the flowing power paths are shown. In this state $\mathrm{L}_{1}, \mathrm{~L}_{2}$ and $\mathrm{L}_{3}$ charge and on the other hand $\mathrm{C}, \mathrm{C}_{1}$ and $\mathrm{C}_{2}$ discharge. Circuit equations of this operation mode are as follows:

$$
\begin{aligned}
& V L=V \text { in } \\
& I C=-I L 1-I L 2 \\
& V L 1=V C+V O 2 \\
& =-V \underline{O} 1 \\
& \text { IC } 1 \text { (1) } \\
& 1 \\
& \text { VL2 } \\
& =V C \\
& =-V \underline{O 2}-
\end{aligned}
$$


$I C 2 \quad I \quad L 1$

$R 2$

\section{B. Operation mode $2 \quad D T<t<T$}

In this state both switches are off. As the result diodes will conduct. The flowing power paths shown in Fig6. Circuit equations of this state are as follows:

$$
\begin{array}{rl}
V L & =V i n-V C-V O 2 \\
I C & =-I L \\
V L 1 & =V O 1 \\
& =--V O 1 \\
I C 1 & I L 1
\end{array}
$$

This paper presents the effectiveness of Luo Converter over Boost Converter (BC) in front end drives. The simulation work has been concluded and results demonstrated the efficiency of Luo converter over Boost Converter. Also, Luo Converter has high transfer voltage gain as compare to Boost Converter. Luo Converters that have very low ripple of voltage and output wave with high quality as compare to Boost Converter.

\section{SIMULATION RESULTS}

Input voltage of proposed converter is considered 30 v. Considering duty cycle equals 70 percent output voltages of the circuit are obtained -230 and +70 volt. This converter supplies 1 A loads. Switching Frequency is considered $100 \mathrm{kHz}$. Circuit elements values are presented in Table 2.

This paper presents the effectiveness of LUO Converter over Boost Converter (BC) in front end drives .The simulation work has been concluded and results demonstrated the efficiency of LUO converter over Boost Converter. Also, LUO Converter has high transfer voltage gain as compare to Boost Converter. LUO Converters that have very low ripple of voltage and output wave with high quality as compare to Boost Converter.

Table 2. CIRCUIT COMPONENTS

\begin{tabular}{|c|c|}
\hline Element & Value \\
\hline Inductor $L$ & $150 \mathrm{UH}$ \\
\hline Inductor $\mathrm{L}_{1}$ & $1 \mathrm{MH}$ \\
\hline Inductor $\mathrm{L}_{2}$ & $1 \mathrm{MH}$ \\
Capacitor $\mathrm{C}$ & $220 \mathrm{Mh}$ \\
\hline Capacitor $\mathrm{C}_{1}$ & $4700 \mathrm{UH}$ \\
\hline & \\
\hline & \\
\hline
\end{tabular}
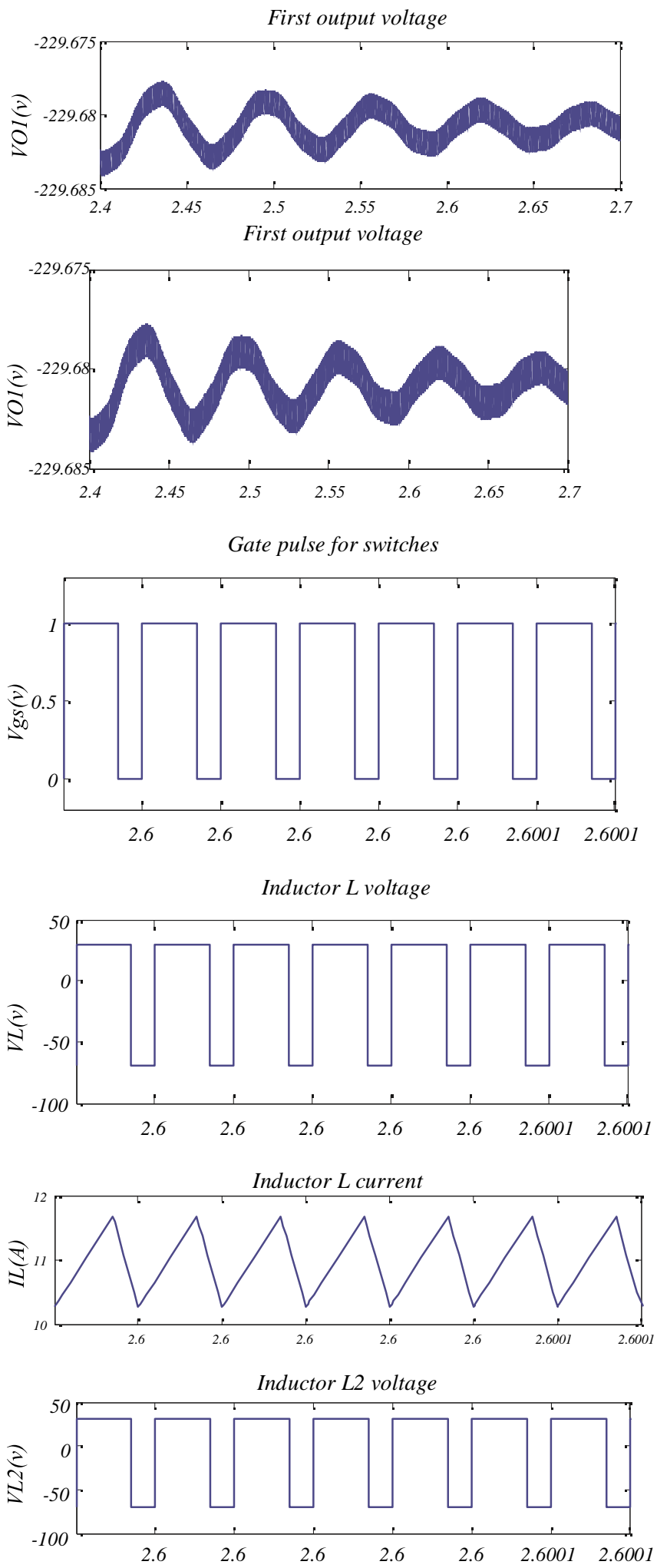


\section{CONCLUSION}

This paper presents the effectiveness of LUO Converter over Boost Converter (BC) in front end drives. The simulation work has been concluded and results demonstrated the efficiency of LUO converter over Boost Converter. Also, LUO Converter has high transfer voltage gain as compare to Boost Converter. LUO Converters that have very low ripple of voltage and output wave with high quality as compare to Boost Converter. In this paper four LUO converter topologies have been compared and analyzed. All these topologies have been designed, modeled, and simulated, to test their performance. All LuoConverters implementing the voltage lift technique, avoid taking too high value of the conduction duty $\mathrm{k}$. For the same value.

\section{REFERENCES}

[1] Agee JT.,and Obok-opok.,A.lasser., MD, et al'(2007).Solar tracker technologies market trends and field applications, (Pg39-44).

[2] Abdel-hardy F.,(2013),Design of solar tracking system engineering tech technology,(pp.391406).

[3]Brunottem Goetzberger.,A,Blieske.,U, (1996),twostage concentrator permitting concentration factor up to 300 with one-axis tracking solar energy,(Pg285300).

[4]lee.,C.Y, and Chou.,P.C, Hiang.,M.C and c. f. lain,'et al'(2018), Sun trackng system a review sensor'( pp.3875-3890).

[5] Dickinson.,WC,(1978),Annual available radiation for fixed and tracking Collectors, $(\mathrm{Pg} 249-51)$.

$[6]$ Siddique.,A.M,Hassan.,W,Aslam.,M.K Aslam.,M.N,'et al'(2018),A prototype model for generating Electricity Using Solar parabolic Dish Stirline Engine and Solar Tracking System (p.p308317).

[7]ShaltoutGhttas.,A,Sabry.,M,(1995),trough concentrator on a PV full tracking system in a hot desert climate renewable energy' (pp.27-32).

[8] Shen.,C,Hua.,C,(1998),Comparative study of peak power tracking applied power electronics ,(pp.679$685)$.

[9]Tomson.,T,(2008),Discrete two positional tracking of solar collectors renewable Energy, $(\mathrm{Pg} 33-93)$.
[10] Muhammad.,H,andRashid.,P,(2004).,

Power Electronics Circuits Devices, and Applications, Third Edition, Pearson Education,(pp.45-53).

[11] Carl Nelson JimWilliams,(1986),Linear Technology,LT1070 Design Manual, (pp.56-87).

[12] Marty Brown.,H,(1996),Practical Switching Power Supply Design, New York: Academic Press, (Pg34-45)

[13]Irving ., M. Gottlieb.,Y,(1993),Power Supplies, Switching Regulators, Inverters, Converters, New York, McGraw-Hill, (Pg 66-78).

[14] Mitchell.,D.M,(1998), DC-DC Switching Regulator Analysis, New York: McGraw-Hill,(PP.4556).

[15] Seguier.,G,(1993),Power Electronic Converters: DC-DC Conversion, New York, Springer Verlag,(Pg 213-234). 